\title{
Enzymes as silage additive. Effect on fermentation quality, digestibility in sheep, degradability in sacco and performance in growing cattle
}

\author{
PEKKA HUHTANEN, KARI HISSA, SEIJA JAAKKOLA and ESKO POUTIAINEN ${ }^{\prime}$ \\ Department of Animal Husbandry, University of Helsinki, \\ SF-00710 HELSINKI, Finland
}

\begin{abstract}
Fungal glucose oxidase and cellulase were used as silage additives in laboratory $(25 \mathrm{l})$, pilot $\left(3 \mathrm{~m}^{3}\right)$ and farm scale $(250 \mathrm{t})$ silos. In $3 \mathrm{~m}^{3}$ scale silos, $\mathrm{pH}$ and the concentration of acetic acid were lower and the concentrations of lactic acid and sugars were higher in the enzyme treated than in untreated silage. The concentration of butyric acid was equal to or lower than in formic acid treated silage in all experiments. Cell wall constituents were degraded in the silo by cellulase and thus more energy was available for lactic acid bacteria. With increasing levels of cellulase application, the disappearance of organic matter (OM) from nylon bags incubated for 1 to $12 \mathrm{~h}$ in the rumen of a dairy cow increased significantly $(\mathrm{P}<0.001$, $\mathrm{P}<0.01$ ) in two different experiments. The level of cellulase had no effect on the ratio N/OM disappeared from nylon bags. Digestibilities of OM in sheep were 75.8, 76.5 and $77.2 \%$ for untreated, formic acid and enzyme treated silage $(\mathrm{P}>0.05)$. On untreated silage diet $\mathrm{N}$ retention tended to be reduced in sheep compared with formic acid or enzyme treated silages. In growing bulls there were no differences in feed intake, growth rate, feed conversion rate, carcass characteristics or OM digestibility between formic acid $(4 \mathrm{l} / \mathrm{t})$ and enzyme treated silage.
\end{abstract}

Index words: silage, additives, enzymes, fermentation, degradability in sacco, growing cattle

\section{Introduction}

Silage additives used to influence fermentation can act either as stimulants by encouraging lactic acid fermentation or as inhibitors by inhibiting completely or partially microbial growth. Fermentation stimulants can be clas-

\footnotetext{
1 Present address: Agricultural Research Centre, SF-31600 Jokioinen, Finland
}

sified as bacterial cultures or as carbohydrate sources.

The effects of bacterial inoculants on silage fermentation have been variable and in many experiments no benefits at all have been seen. WoOlFord and SAwCZYC (1984) did not find any notable influence on the rate of acidification or promotion of homolactic fermentation by selected cultures of lactic acid bac- 
teria and these also tended to increase the amount of soluble protein and deamination.

Carbohydrate rich materials such as sugars, molasses and cereals have been added to silage crop in order to supply energy for lactic acid bacteria. In his review, McDonAlD (1981) notes that molasses has been shown to decrease $\mathrm{pH}$ and the amount of ammonia $\mathrm{N}$ in silage. CASTLE and WATSON (1985) did not record any differences in the performance of dairy cows fed formic acid or molasses treated silages. A disadvantage of using carbohydrate rich materials is the relatively high concentrations required.

Forage plants have a large reserve of carbohydrates, but these occur mainly in the form of polysaccharides which cannot be used as an energy source by lactic acid bacteria in silage. In theory, the addition of enzymes able to hydrolyse forage polysaccharides would increase the fermentation capacity of silage by releasing fermentable substrate. The cellulolytic enzymes would also promote cellular breakdown and render cell contents more accessible to silage microflora.

The objectives of the present studies were to investigate the effect of enzymes on silage fermentation, degradation rate in sacco, digestibility in sheep and on the performance of growing bulls. The silages were made in laboratory, pilot and farm scale silos.

\section{Materials and methods}

In two experiments $5 \mathrm{~kg}$ of chopped grass was wilted for $4 \mathrm{~h}$ in order to increase dry matter (DM) content to about $25 \%$, and then ensiled into 251 laboratory silos. The herbage contained $19.0 \%$ of crude protein and $22.6 \%$ of crude fibre in Exp. 1 and 15.6 and $25.2 \%$ in Exp. 2. The treatments were as follows: untreated control, formic acid $(5 \mathrm{l} / \mathrm{t})$, glucose oxidase (GO) and GO + 100, 200, $400,800,1600$ or $3200 \mathrm{ml} / \mathrm{t}$ of cellulase. Formic acid was applied as AIV II solution (80\% formic acid, $2 \%$ orthophosphoric acid) in all the experiments. After $59 \mathrm{~d}$ (Exp. 1) and $86 \mathrm{~d}$ (Exp. 2) the silos were opened and analyzed for DM, organic matter (OM), ash, nitrogen $(\mathrm{N})$, true protein, ether extract, crude fibre, neutral detergent fibre ( 1 JF), acid detergent fibre (ADF), lignin (ADL), $\mathrm{pH}$, sugars, lactic acid, volatile fatty acids (VFA), ammonia and soluble $\mathrm{N}$.

Nylon bag (porosity $40 \mu \mathrm{m}$ ) incubations were made in the rumen of a dairy cow fed at the level of 2.8 times maintenance, with forage $60 \%$ of DM. The silages incubated in triplicate were withdrawn after 2, 5, 9, 24 and $48 \mathrm{~h}$ in Exp. 1 and after 1, 3, 6, 12, 24 and $48 \mathrm{~h}$ in Exp. 2. Residues were analysed for $\mathrm{DM}, \mathrm{OM}$ and $\mathrm{N}$ and some treatments also for NDF. The values for degradation constants were calculated using the formula of ØRSKOV and McDonald (1979)

$p=a+b\left(1-e^{-c t}\right)$.

For the digestibility experiment (Exp. 3) silages were made in $3 \mathrm{~m}^{3}$ glass fibre silos from first cut timothy sward. The grass was wilted for $4 \mathrm{~h}$ except the direct cut formic acid treated silage. The treatments were untreated control, formic acid direct cut $(4.5 \mathrm{l} / \mathrm{t})$, formic acid pre-wilted $(4 \mathrm{l} / \mathrm{t}), \mathrm{GO}+$ hemicellulase $(150$ $\mathrm{ml} / \mathrm{t})+$ cellulase $(200 \mathrm{ml} / \mathrm{t})($ Enzyme A) and hemicellulase $(150 \mathrm{ml} / \mathrm{t})+$ cellulase $(200$ $\mathrm{ml} / \mathrm{t}$ ) (Enzyme B). The digestibility trial was carried out with 5 sheep using a $5 \times 5$ Latin square design.

The material for the feeding trial (Exp. 4) was second cut timothy red clover sward (red clover $35-40 \%$ of DM). After wilting for $4 \mathrm{~h}$ the grass was ensiled into a $250 \mathrm{t}$ bunker silo either with formic acid $(4 \mathrm{l} / \mathrm{t})$ or $2-3 \mathrm{~d}$ later with enzyme mixture (GO + cellulase 150 $\mathrm{ml} / \mathrm{t}$ ). A feeding trial of $210 \mathrm{~d}$ was carried out with 24 bulls using $2 \times 2$ factorial design. Both silages were supplemented with barley or barley + fishmeal (FM). Barley was fed at the level of $40 \mathrm{~g} / \mathrm{kg} \mathrm{W}^{0.75}$ on an air dry basis. In the FM group $0.25 \mathrm{~kg}$ of barley was replaced by FM. In vivo digestibility was determined at the liveweight of $250-300 \mathrm{~kg}$ using acidinsoluble ash as digestibility marker (VAN Keulen and Young 1977). 


\section{Results and discussion}

The breakdown of various fibre fractions increased during the ensilage period with increasing level of cellulase (Fig. 1). The effect was proportional to the square root of cellulase activity. In Exp. 2 with longer ensilage period and more mature material, the effect of cellulase on ADF, cellulose and crude fibre was like that in Exp. 1, but the effect on NDF was greater indicating the hydrolysis of hemicellulose and the hemicellulose activity of the enzyme mixture. In the normal ensilage process the breakdown of hemicellulose is caused also by plant enzymes and later, when $\mathrm{pH}$ is low, by acid hydrolysis (McDonald 1981).

All the silages were well preserved. Formic acid almost completely inhibited fermentation in the laboratory silos $(4 \mathrm{~kg})$. Presumably at

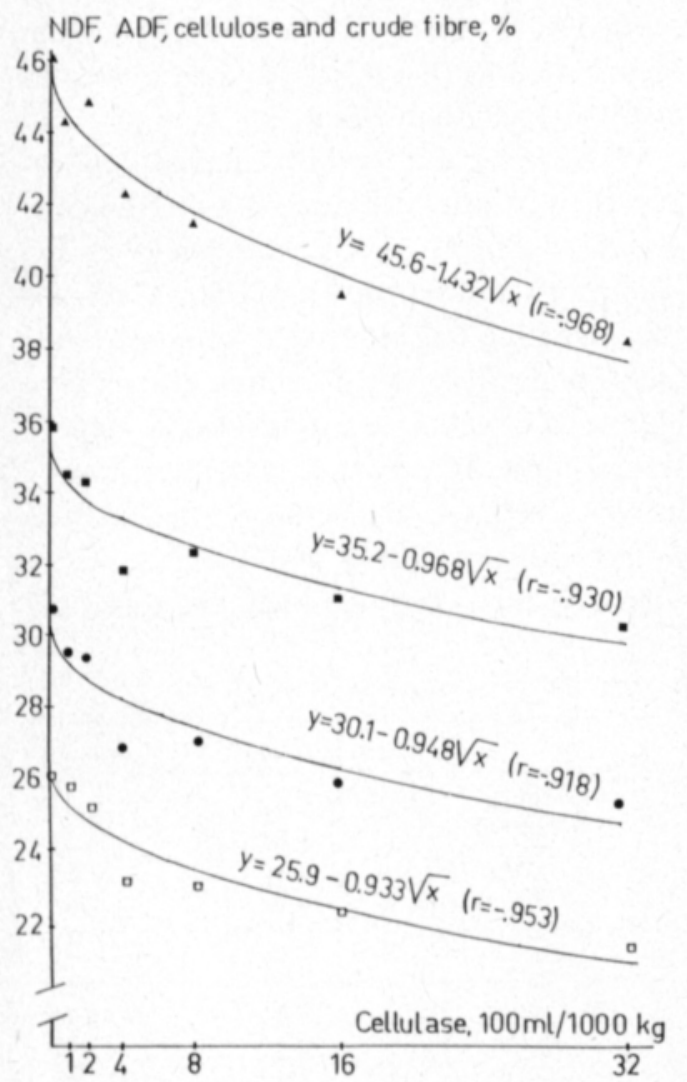

Fig. 1. The effect of enzyme level on NDF $\Delta$, ADF cellulose and crude fibre $\square$ contents of silage $(\%$ of DM) in Exp. 2.

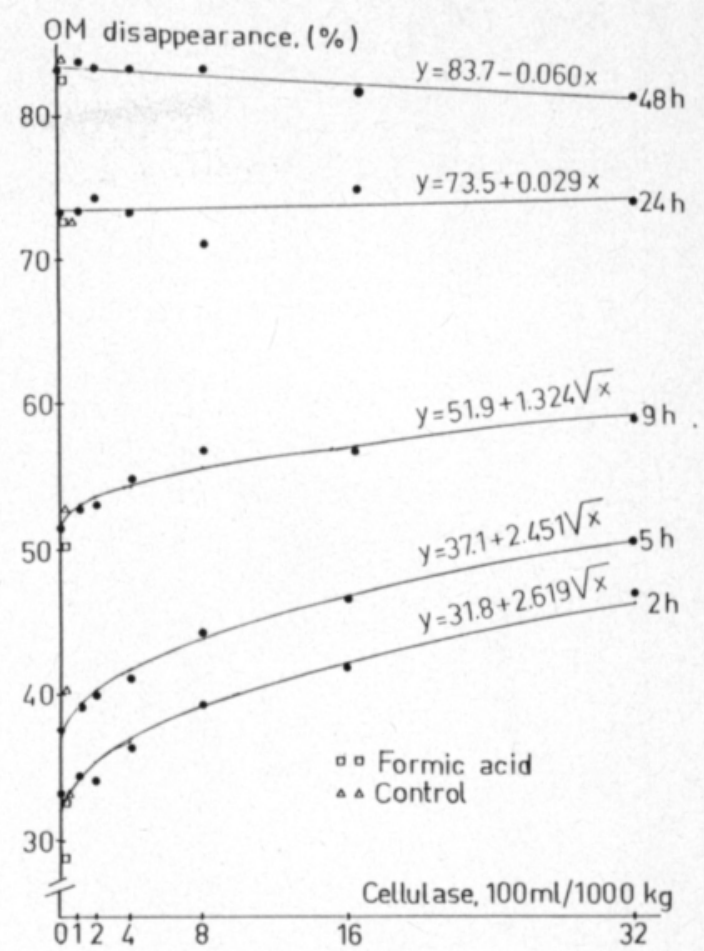

Fig. 2. The effect of enzyme level on silage OM disappearance ( $\%$ of total $\mathrm{OM})$ from the nylon bags in Exp. 1.

the high levels of addition the bacteriostatic action of formic acid and consequent suppression of lactic acid production allowed the $\mathrm{pH}$ to increase in response to the release of buffering constituents from plant tissue. With increasing levels of cellulase the concentration of residual sugars increased and there was also some increase in the concentration of lactic acid. No effect on true protein contents or the ratio ammonia $\mathrm{N}$ : total $\mathrm{N}$ was found with increasing levels of cellulase, but the ratio soluble $\mathrm{N}$ : total $\mathrm{N}$ increased, presumably because of the breakdown of cell walls and subsequent release of cell contents.

The disappearance of OM from nylon bags increased with the level of cellulase addition, especially after shorter incubations (Figs. 2 and 3). After an incubation of $48 \mathrm{~h}$ there were no differences in the extent of OM degradation between the treatments. The very rapidly degradable fraction $a$ increased with the level of cellulase and in time degradable fraction 


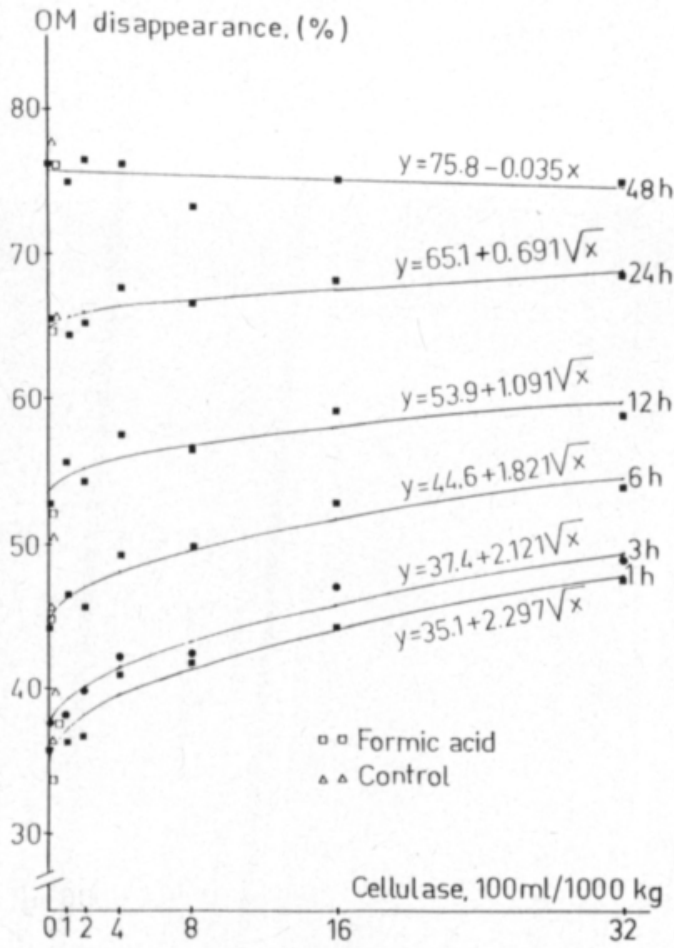

Fig. 3. The effect of enzyme level on silage OM disappearance $(\%$ of total $\mathrm{OM})$ from the nylon bags in Exp. 2.

$b$ decreased. The effect of treatments on $c$ (the rate of degradation of fraction $b$ ) was inconsistent in Exp. 1, but in Exp. 2 all enzyme treated silages had a higher rate of OM degradation than untreated or formic acid treated silages. Cellulase treatment had the same pattern of response on $\mathrm{N}$ as on OM disappearance. The ratio $\mathrm{N}$ : OM that disappea- red during the first 2 or 3 hours was $55-63$ $\mathrm{g} \mathrm{N} / \mathrm{kg} \mathrm{OM}$ in Exp. 1 and $43-51 \mathrm{~g}$ in Exp. 2 being slightly lower in formic acid treated silage than in other silages. This ratio was not affected by the level of cellulase. The effect of increased $\mathrm{N}$ loss after short incubations on $\mathrm{N}$ or microbial $\mathrm{N}$ flow might be negative. However, Chamberlain et al. (1982) did not record any response of $\mathrm{N}$ flow into the duodenum when the level of formic acid was increased from 0 to $5.9 \mathrm{l} / \mathrm{t}$, and the undegradable fraction of silage $\mathrm{N}$ was increased only from 22 to $28 \%$. It seems that partial limitation of proteolysis can be achieved in the silo by the addition of high levels of formic acid, but protein spared from hydrolysis in the silo seems to be degraded by the rumen microbes.

Part of the response in the OM loss can be explained by increased $\mathrm{N}$ loss with higher levels of cellulase. However, the loss of $\mathrm{N}$-free $\mathrm{OM}$ after incubations for 3,6 and $12 \mathrm{~h}$ increased from 33.0 to $41.7 \%(\mathrm{P}<0.001)$, from 39.9 to $46.8 \%(\mathrm{P}<0.001)$, and from 48.4 to $54.0 \%(\mathrm{P}<0.01)$ in Exp. 2.

With the highest level of cellulase application the potential degradability of NDF was decreased (Table 1), but this could be explained by the breakdown of cell walls in the silo. Lag time was reduced by cellulase treatment, but in Exp. 1 with young grass a very high level of cellulase was needed to achieve this response. By contrast, with more mature material in Exp. 2 the same response was found with the level of $400 \mathrm{ml} / \mathrm{t}$.

In Exp. 3 enzyme treatment decreased $\mathrm{pH}$

Table 1. The degradation constants of NDF disappearance from the nylon bags in Exp. 1 and Exp. 2 .

\begin{tabular}{lccccc}
\hline Exp. 1 & $a+b$ & $c$ & r & Lag time (h) & Res. s.d. \\
\hline Control & 76.0 & .0608 & .9999 & 2.6 & 0.92 \\
Formic acid & 74.4 & .0677 & .9977 & 3.0 & 3.23 \\
GO + $400 \mathrm{ml}$ & 73.5 & .0620 & .9998 & 2.5 & 1.54 \\
GO + C 3200 ml & 65.5 & .0644 & .9987 & 0.9 & 2.96 \\
\hline Exp. 2 & & & & 2.8 \\
\hline Control & 68.3 & .0385 & .9984 & 4.2 & 4.21 \\
Formic acid & 62.5 & .0376 & .9996 & 1.7 & 1.57 \\
GO +C 400 ml & 61.5 & .0403 & .9993 & .9990 & 1.26 \\
GO +C $3200 \mathrm{ml}$ & 55.5 & .0321 & & & 2.30 \\
\hline
\end{tabular}

$\mathrm{GO}=$ glucose oxidase, $\mathrm{C}=$ cellulase 
Table 2. Fermentation quality of experimental silages in Exp. 3.

\begin{tabular}{|c|c|c|c|c|c|c|}
\hline & $\begin{array}{c}\text { Formic acid } \\
\text { direct-cut }\end{array}$ & $\begin{array}{c}\text { Formic acid } \\
\text { pre-wilted }\end{array}$ & Control & Enzyme A & Enzyme B & SEM \\
\hline $\mathrm{pH}$ & $4.06^{c}$ & $3.98^{c}$ & $4.40^{d}$ & $3.95^{\mathrm{c}}$ & $3.96^{c}$ & 0.03 \\
\hline \multicolumn{7}{|l|}{ In dry matter, $\%$} \\
\hline Sugars & $1.53^{\mathrm{d}}$ & $3.62^{c}$ & $0.17^{e}$ & $0.80^{\text {de }}$ & 0.89 de & 0.18 \\
\hline Lactic acid & $6.34^{e}$ & $6.38^{e}$ & $9.31^{d}$ & $13.26^{c}$ & $13.05^{c}$ & 0.54 \\
\hline Acetic acid & $1.82^{\mathrm{de}}$ & $1.38^{\mathrm{e}}$ & $3.03^{\mathrm{c}}$ & $2.33^{\text {ed }}$ & $2.33^{\mathrm{cd}}$ & 0.17 \\
\hline Propionic acid & 0.08 & - & 0.07 & - & - & 0.03 \\
\hline Ratio lactic: acetic & $4.1^{\mathrm{ab}}$ & $4.8^{\mathrm{ab}}$ & $3.1^{\mathrm{b}}$ & $5.7^{\mathrm{a}}$ & $5.6^{\mathrm{a}}$ & 0.47 \\
\hline \multicolumn{7}{|l|}{ In total $\mathrm{N}, \%$} \\
\hline Ammonia $\mathrm{N}$ & $6.3^{\mathrm{de}}$ & $5.2^{e}$ & $11.3^{\mathrm{c}}$ & $7.2^{\mathrm{d}}$ & $7.2^{\mathrm{d}}$ & 0.35 \\
\hline Soluble N & $60.5^{\text {cd }}$ & $58.9^{d}$ & $70.4^{c}$ & $67.9^{\text {dd }}$ & $66.9^{\mathrm{cd}}$ & 2.0 \\
\hline
\end{tabular}

Means with different letters were significantly different $a, b(P<0.05), c, d, e(P<0.01)$

Table 3. Feed intake and the performance data in growing bulls in Exp. 4.

\begin{tabular}{|c|c|c|c|c|c|c|c|c|c|}
\hline & \multicolumn{2}{|c|}{ Formic } & \multicolumn{2}{|c|}{ Enzyme } & \multicolumn{2}{|c|}{ Silage } & \multicolumn{2}{|c|}{ Protein } & \multirow[b]{2}{*}{ SEM } \\
\hline & Contr. & FM & Contr. & FM & FA & Enzyme & Contr. & FM & \\
\hline \multicolumn{10}{|l|}{ DM intake', kg/d } \\
\hline Silage & 3.68 & 3.81 & 3.57 & 3.69 & 3.74 & 3.63 & 3.63 & 3.75 & 0.11 \\
\hline Barley & 2.29 & 2.09 & 2.23 & 2.11 & 2.19 & 2.17 & 2.26 & 2.10 & 0.07 \\
\hline Fishmeal & - & 0.22 & - & 0.22 & 0.11 & 0.11 & - & 0.22 & 0.00 \\
\hline Total & 5.97 & 6.12 & 5.80 & 6.02 & 6.05 & 5.91 & 5.88 & 6.07 & 0.16 \\
\hline $\mathrm{DM} \mathrm{g} / \mathrm{kg} \mathrm{W}^{0.75}$ & 86.7 & 88.2 & 86.8 & 85.8 & 87.5 & 86.3 & 86.8 & 87.0 & 1.2 \\
\hline Initial weight, $\mathrm{kg}$ & 181.0 & 175.5 & 179.3 & 178.0 & 178.2 & 178.7 & 180.2 & 176.8 & 12.1 \\
\hline Final weight, kg & 401.0 & 406.2 & 386.7 & 411.3 & 403.6 & 399.0 & 393.8 & 408.7 & 11.5 \\
\hline Daily gain, g & 1064 & 1137 & 1004 & 1141 & 1100 & 1072 & $1034^{\mathrm{a}}$ & $1139^{\mathrm{b}}$ & 35 \\
\hline \multicolumn{10}{|l|}{ Feed conversion } \\
\hline $\mathrm{Kg} \mathrm{DM} / \mathrm{kg}$ gain & 5.63 & 5.40 & 5.85 & 5.31 & 5.52 & 5.58 & 5.74 & 5.36 & 0.18 \\
\hline $\mathrm{ME} \mathrm{MJ/kg} \mathrm{gain}$ & 63.6 & 61.2 & 64.9 & 59.2 & 62.4 & 62.1 & 64.2 & 60.2 & 2.1 \\
\hline Carcass weight, kg & 205.2 & 206.7 & 197.0 & 210.8 & 205.9 & 203.9 & 201.1 & 208.8 & 7.2 \\
\hline Dressing- $\%$ & 50.8 & 50.7 & 50.9 & 51.2 & 50.7 & 51.0 & 50.9 & 50.9 & 0.5 \\
\hline
\end{tabular}

1 On oven DM basis, FM= fishmeal, FA= formic acid

Means with different letters significantly different $\mathrm{a}, \mathrm{b}(\mathrm{P}<0.05)$

and the concentrations of acetic acid and ammonia $\mathrm{N}$ and increased the concentrations of lactic acid and residual sugars compared with untreated control (Table 2). Enzyme treatment encouraged homofermentative lactic acid bacteria and the ratio lactic acid:acetic acid was the most favourable in enzyme silages. Apparently in the absence of fermentation inhibitors the sugars from cell wall hydrolysis are used mainly for lactic acid production.

The digestibility of OM was $76.2,76.5$, $75.8,77.1$ and $77.2 \%$ for direct cut formic acid, pre-wilted formic acid, untreated, enzyme A and enzyme B treated silages and $\mathrm{N}$ retentions were $2.5,2.9,1.4,2.0$ and $2.9 \mathrm{~g} / \mathrm{d}$, respectively.

Both silages in Exp. 4 were well preserved in the bunker silo. The enzyme treated silage had a higher concentration of lactic acid (11.2 vs. $8.6 \%$ ), acetic acid (3.8 vs. $2.1 \%$ ), ammonia $\mathrm{N}(8.9$ vs. $5.9 \%$ of total $\mathrm{N})$ and soluble $\mathrm{N}(49.4$ vs. $41.8 \%$ of total $\mathrm{N})$ and lower concentration of sugars (1.1 vs. $0.5 \%)$. However, DM intakes of the two silages were similar on oven DM basis (Table 3). Differences between the silages in growth rate, feed conversion and carcass characteristics were small and insignificant. FM, on the other hand, improved significantly $(\mathrm{P}<0.05)$ the liveweight gain (Table 3). One animal in the 
enzyme silage + barley group had leg injuries, which partly explains the insignificant $(\mathrm{P}>0.05)$ interaction between the type of silage and protein supplementation.

Enzyme treatment reduced significantly $(\mathrm{P}<0.001)$ the digestibility of crude fibre and improved $(\mathrm{P}<0.001)$ that of the ether extract compared with formic acid treated silage. The lower crude fibre digestibility is most likely explained by enzymatic cell wall digestion in the silo, but probably the slightly later harvesting time also had some effect. It seems that the cellulase system first attacks the most easily digestible fraction of fibre in the silo and the fraction which is left is less digestible in the animal than the original fibre. There was a significant $(\mathrm{P}<0.01)$ interaction between the silage and protein supplementation: FM clearly improved the digestibility of enzyme treated silage, but had a slightly negative effect with formic acid silage. Possibly enzyme silage requires a different supplement than acid treated silage to optimize cell wall digestion in the rumen.

In conclusion, enzyme treatment encouraged lactic acid fermentation and also reduced ammonia $\mathrm{N}$ compared with untreated control silage. No adverse effects relative to formic acid silage were found on $\mathrm{N}$ retention in sheep or feed intake and liveweight gain in growing bulls. The advantages of biological additives over acids are that they are safer to handle, less corrosive to machinery and easier to transport.

\section{References}

Chamberlain, D.G., Thomas, P.C. \& Wait, M.K. 1982. The rate of addition of formic acid to grass at ensilage and the subsequent digestion of the silage in the rumen and intestines of sheep. Grass and Forage Sci. 37: 159-164.

CAstle, M.E. \& W ATSON, J.N. 1985. Silage and milk production: studies with molasses and formic acid as additives for grass silage. Grass and Forage Sci. 40: 85-92.

McDonald, P. 1981. Biochemistry of silage. 226 p. Chichester. John Wiley \& Sons.

Ørskov, E.R. \& McDonald, I. 1979. The estimation of protein degradability in the rumen from incubation

\section{SELOSTUS}

\section{Entsyymit nurmirehun säilöntäaineena.}

Vaikutus käymiseen, sulavuuteen lampailla, rehun hajoamisnopeuteen in sacco sekä tuotantoon lihanaudoilla

Pekka Huhtanen, Kari Hissa, Seija Jaakkola ja Esko Poutiainen ${ }^{1}$

Helsingin yliopisto, kotieläintieteen laitos, 00710 Helsinki

Homeiden tuottamaa glukoosioksidaasia ja sellulaasia kăytettiin nurmirehujen säilöntăaineena laboratorio-

\footnotetext{
' Nykyinen osoite: Maatalouden tutkimuskeskus,
} 31600 Jokioinen measurements weighted according to rate of passage. J. agric. Sci., Camb. 92: 499-503.

VAn Keulen, J. \& Young, B.A. 1977. Evaluation of acidinsoluble ash as a natural marker in ruminant digestibility studies. J. Anim. Sci. 44: 282-287.

WoOlford, M.K. \& SAwczyc, M.K. 1984. An investigation into the effect of cultures of lactic acid bacteria on fermentation in silage. 2. Use of selected strains in laboratory scale silages. Grass and Forage Sci. 39: 149-158.

Ms received December 18, 1985
(25 1), pilot ( $\left.3 \mathrm{~m}^{3}\right)$ ja maatilasiiloissa (250 t) suoritetuissa kokeissa. Entsyymikäsiteltyjen rehujen $\mathrm{pH}$ ja etikkahappopitoisuus olivat alhaisempia ja maitohappo- ja sokeripitoisuus korkeampia kuin painorehulla $3 \mathrm{~m}^{3}$ : $\mathrm{n}$ siiloissa. Voihappopitoisuus oli kaikissa kokeissa entsyymirehuil- 
la sama tai alhaisempi kuin muurahaishapporehulla (AIV-2). Sellulaasi pilkkoi rehun solunseinämäaineita siilossa ja vapautti siten sokereita maitohappobakteereiden käytettåväksi. Kahdessa eri nailonpussikokeessa lypsylehmăllä orgaanisen aineen pötsihajoavuus kohosi merkitsevästi $(\mathrm{P}<0.001, \mathrm{P}<0.01) 1-12$ tunnin inkuboinneilla entsyymitason kohotessa. Typen ja orgaanisen aineen hajoavuuksien suhteeseen ei sellulaasitasolla ollut vaikutusta. Painorehun, muurahaishapolla sekă entsyymeillă săilöt- tyjen rehujen orgaanisen aineen sulavuudet păsseillã olivat vastaavasti $75.8,76.5$ ja $77.2 \%(P>0.05)$. Typen pidättyminen oli painorehulla hieman alhaisempi kuin muurahaishapolla tai entsyymeillă säilötyillä rehuilla. Lihanaudoilla rehun syönnissä, kasvussa, rehun hyvăksikãytőssä, teuraslaadussa ja orgaanisen aineen sulavuudessa ei ollut eroa AIV-2:lla $(4 \mathrm{l} / \mathrm{t})$ tai entsyymeillă săilöttyjen rehujen vălillă. 